\title{
ROZHRANÍ ÚSTAVNÍHO A SPRÁVNÍHO PRÁVA
}

\author{
RICHARD POMAHAČ
}

\begin{abstract}
The Interface between Constitutional and Administrative Law
Constitutional and administrative law are two related branches of law. But are the boundaries separating constitutional and administrative law truly clear? Many excellent experts in public law have already answered this question. However, as the legal system evolves, the answer to this question can be neither complete nor definitive. Nevertheless, it is possible to mark a number of bright and dark sides of the normative duality of constitutional and administrative law. Attention is focused on the constitutionalization of administrative law, but no less important is the deconstitutionalization of public administration in conditions of over-regulation connected with fragmentary and inconsistent legislation. However, it is not just a question of the integrity of the legal order. There are also a number of practical problems in the sphere of disputes resolution using dual argumentation.
\end{abstract}

Keywords: constitutional law; administrative law; interface; constitutionalisation and deconstitutionalisation of administrative law

Klíčová slova: ústavní právo; správní právo; rozhraní; konstitucionalizace a dekonstitucionalizace správního práva

DOI: $10.14712 / 23366478.2021 .37$

\section{1. ÚVOD}

O ústavním a správním právu se často uvažuje jako o právních odvětvích, která k sobě mají velmi blízko. V učebnicích se dočíáme, že nesporně nejužší vazby má správní právo k právu ústavnímu, a to i s ohledem na to, že veřejným právem v užším slova smyslu se zpravidla chápe právě právo správní, př́ípadně včetně práva ústavního. ${ }^{1}$

Jsou však hranice oddělující ústavní a správní právo opravdu zřetelné? A co tvoří styčné body rozhraní správního a ústavního práva? Pokusme se prozkoumat tyto otázky v kontextu dualismu správního a ústavního práva a v souvislostech konstitucionalizace správního práva.

Rozhraní správního a ústavního práva je oblastí, v níž se obě odvětví stýkají a kde pochopitelně může docházet k řadě nedorozumění. Nedělejme si iluze, že při vzrůstající

1 SLÁDEČEK, V. Obecné správní právo. Praha: Wolters Kluwer ČR, 2013, s. 37 a 42. 
komplikovanosti právního systému lze narýsovat hranice, které by byly nepřekročitelné, zvláště v době, kdy se snažíme dát ústavnímu i správnímu právu další prostor k uplatnění. Nepřehlédnutelné jsou v této souvislosti úvahy o fragmentarizaci státu i práva a lze patrně souhlasit s tezí, že fragmentární stát budoucnosti by měl být postaven nejen na „, hmatatelné demokracii, ale též na vertikále vlády práva založené na ústředním motivu základnich lidských práv ". 2 Atributy fragmentarizace a vertikality vstupují vehementně do prostoru, v němž se ústavní a správní právo dotýkají, což dodává relevanci úvahám o tom, zda se obě odvětví přibližují či vzdalují a zda právníci, akcentující různá konstitucionalistická a administrativistická východiska, dobře komunikují.

\section{DUALISMUS SPRÁVNÍHO A ÚSTAVNÍHO PRÁVA}

Má-li správní právo k právu ústavnímu velmi úzké vazby, je to pro interpretaci a aplikaci práva spiše výhodou, nebo nevýhodou? V učebnicích správního práva bývá odpověd' často skryta pod zjišsěním, že se správním právem se ústavní právo, jehož předmětem je úprava základních vztahů ve státě (ústava), zčásti prolíná. ${ }^{3}$ Vazby mezi těmito odvětvími mají interferenční charakter, takže se při prolínání nejenom vzájemně zesilují, ale i ruší. Dualismus správního a ústavního práva představuje určitou variantu celostního nahlížení na právní systém. To, jakou variantu přijmeme, souvisí do značné míry s tím, co rozumíme pod pojmem veřejné právo.

Diferenciace ústavního a správního práva vynikla v historickém vývoji západoevropského práva s významnými přesahy do práva USA a jako taková tvoří i součást makrokomparativní analýzy. Srovnávací výzkum bývá zpravidla založen na premise, že jak ústavní, tak správní právo stanoví, udržuje a omezuje vládní činnost. Rozdíly v právních a politických systémech však způsobily značné rozdíly ve vnímání způsobu vzájemného propojení prvků regulace a kontroly. Michal Tamir v této souvislosti vyjádřil hypotézu, že zatímco vývoj v určitých státech (jmenuje např́ílad Británii, Izrael a Německo) vedl k tomu, že se vcelku harmonicky podrobují všechny vládní činnosti jednotlivým pravidlům ústavního a správního práva, $\mathrm{v}$ mnoha dalších demokratických zemích hraje správní právo spíše jen druhé housle a projevuje se tendence k přezkumu určitých otázek výhradně pomocí ústavních principů. ${ }^{4}$

Tuto hypotézu autor dobře vysvětluje na př́ípadu vynucování pravidla o používání bezpečnostních pásů $\mathrm{v}$ automobilech. Mimochodem, př́ípad bezpečnostních pásů má i zajímavou historickou souvislost. Vynález pásů spadá do epochy, v níž se mělo za to, že rozum vítězí nad pocity a pověrami. George Cayley, který se na konci 18. století zabýval konstrukcí malého funkčního letounu, vybavil kluzáky, na nichž létal, bezpečnostními pásy. Cayley se později věnoval i politice a stal se na určitou dobu zákono-

2 HAVLÍČEK, K. Osudné vynálezy lidstva: obtižná cesta $k$ fragmentárnímu státu a osvícenému právu. Praha: Academia, 2020, s. 489.

3 KOPECKÝ, M. Správní právo: obecná část. Praha: C. H. Beck, 2019, s. 13.

4 TAMIR, M. Public Law as a Whole and Normative Duality: Reclaiming Administrative Insights in Enforcement Review. Texas Journal on Civil Liberties and Civil Rights [online]. 2006, Vol. 12, No. 1 [cit. 2021-05-18]. Dostupné na: https://ssrn.com/abstract=1011404. 
dárcem. Dodnes bývá citována jeho věta o tom, že by mělo být pozitivním zákonem stanoveno, že jedou-li dva vlaky proti sobě, musí jet po odlišných kolejích.

Během posledních dvou století se pohled na to, co lze prostřednictvím správního práva regulovat a kontrolovat, pronikavě měnil. Bezpečnostní opatření mohutněla v souvislosti s tím, jak se měnila společnost a technika. Některé elementární otázky se však vracely k téže podstatě, jak dobře ukazuje vlivný rozsudek Nejvyššího soudu USA v případě bezpečnostních pásů. ${ }^{5}$ Skutkové okolnosti případu jsou přehledné. 26. března 1997 Gail Atwaterová vezla své dvě malé neposedné děti domů z fotbalového tréninku v Lago Vista v Texasu. Situace je to docela typická pro každodenní způsob života v postmaterialistické společnosti. Jak to mají matky těžké, názorně ukazuje i řadový rodinný film z roku 2008 Soccer Mom. Texaský policista znal paní Atwaterovou jako řidičku, která jezdí po městě občas bez pásů, a již dříve viděl její děti, jak se v pick-upu všelijak nebezpečně pohybují. Rozhodl se pro razantní zásah. Auto bylo zabaveno, děti si odvezl přivolaný rodinný přítel a řidička byla zadržena a dopravena do policejní cely, kde strávila asi hodinu. Ve věci rozhodl téměř neprodleně municipální soudce. Paní Atwaterová byla propuštěna na kauci 310 dolarů. Pokud šlo o celkovou „útratu“, pak 150 dolarů činila pokuta, 150 dolarů činily soudní výdaje a 110 dolarů poplatek za vydání zabaveného vozidla.

Př́ípad z Lago Vista se stal velice diskutovaným případem. Některé z kladených otázek byly docela zásadní. Jsou bezpečnostní pásy při jízdě ve městě opravdu tím, co stojí za tak velkou legislativní i policejní pozornost? Lze si představit právo jezdit v automobilu nepřipoután? A pokud ne, jak na to má reagovat obec či stát? Ve hře byly pochopitelně i úvahy vycházející z tradičních představ o tom, co je a co není úlohou veřejné správy. Koneckonců diskuse o bezpečnostních pásech vzbuzovaly v USA vášnivou debatu již ve 40. a 50. letech minulého století. I když byly věcné argumenty odpůrců spíše okrajové (pásy by mohly způsobit vnitřní zranění či bránit únikům z aut ponořených ve vodě), byly o to hlasitěji pronášeny. Když se jeden z unijních států, Wisconsin, rozhodl počátkem 60. let minulého století povinnost užívat bezpečnostní pásy zavést, sklidil za to posměch, ba opovržení v mnoha jiných státech. Mluvilo se dokonce o podkopávání občanských svobod. Jen pro srovnání dodejme, že u nás byla v roce 1967 vyhláškou zavedena povinnost používat bezpečnostní pásy na předních sedadlech aut vybavených povinně bezpečnostními pásy při jízdách mimo obec. Automobily Moskvič a Volha dostaly výjimku, nebot' neměly kotevní úchyty pro pásy. Administrativní mlýny mlely pomalu, ale jistě. Na začátku 90 . let začaly být pásy povinně použíány i při jízdě v obcích.

Ve Spojených státech amerických proběhla na začátku první dekády tohoto století rozsáhlá propagační kampaň Click It or Ticket. Američanům, kteří tráví v automobilech většinou dost času, se připomínalo, že pokud jedou v automobilu, nejsou ve svobodném prostoru, protože policisté mohou nepřipoutaným jezdcům dávat pokutové lístky. Blokové pokuty se jevily jako nezpochybnitelná reakce vykonavatelů práva. Ve věci Atwater však nedlouho před touto kampaní soudci nižších soudů a pak většinově i soudci senátu Nejvyššího soudu zavrhli myšlenku, že ústava či zákon za daných okolností

Atwater v. City of Lago Vista, 532 U.S. 318 (2001). 
umožňují toliko udělení pokuty a nic víc. Zásah, který vedl v tomto případě k omezení osobní svobody, nebyl podle soudců ani neústavní, ani protiprávní. Nechyběla totiž důvodná zjištění vedoucí rozumnou a obezřetnou úřední osobu k domněnce, že je s vysokou pravděpodobností páchán delikt. Podle této logiky by tedy mohla být vedena i kampaň Buckled or Booked (připásaný nebo zabáslý).

Mnozí právníci v této souvislosti vyjádřili své přesvědčení, že něco v právu zaskřípalo. Soudci se zabývali toliko ústavním opodstatněním zadržení. Jedoucí vůz s řidičkou s rozepnutým pásem a poskakujícími malými dětmi nepochybně vzbuzuje podezření ve společnosti, která si klade za cíl účinně chránit život a zdraví. Chování policisty v takovéto situaci závisí na řadě okolností. Razantní reakce bude spíše výjimečná. Tak např́íklad větší smůlu mohou mít ti, kteří jedou bez pásu v době policejní bezpečnostní akce, anebo ti, kteří měli s policií již dříve problémy, chovají se arogantně apod. Rozlišení na této úrovni však už je více než s ústavním právem spojováno s právem správním, protože jde o problém míry administrativní diskrece. Paní Atwaterová měla možná jen větší smůlu, než je obvyklé.

Řešení případu z Lago Vista, které by možná bylo lepší, lze nazvat řešením s pomocí normativní duality. Správní orgány musí při výkonu diskreční pravomoci dodržovat jak ústavní normy, tak správní právo. Jsou to totiž argumenty týkající se stupně volnosti správního uvážení, které vedou k závěru, že méně je někdy i více. Click It or Ticket i Buckled or Booked jsou sice varianty ústavně i administrativně možné, pravidlo umírněnosti však velí preferovat jednodušší řešení před takovým, které může vyvolávat kontroverzi. Normativní dualita však není fenoménem současnosti. Př́ípad z Lago Vista jen ilustruje to, co bychom měli docenit obecně a pochopit v historickém vývoji veřejného práva.

Často nepochopena zůstává historizující úvaha o tom, že teorie iuris politiae obhajovala právo úřadů zasahovat do všech sfér života lidí s odůvodněním, že obecný zájem musí mít přednost před zájmem soukromým. ${ }^{6}$ Co to byla teorie iuris politiae, není dnes už mnoha právníkům zcela zřejmé. Na tomto místě postačí říci, že jde o souhrnné označení pro veřejné právo ve středoevropském právním systému druhé poloviny 18. a první poloviny 19. století. Pokud bychom měli uvést, které spisy jsou vlajkovými loděmi této teorie, uvedli bychom patrně Initia iuris politiae Germanorum (autor Heumann von Teutschenbrunn, vydáno 1757) a Juris politiae ex uno securitatis jurumque defendendorum principio repetiti, et ad artis formam redacti, brevis delineatio (autor Carl Friedrich Wilhelm Gerstaecker, vydáno 1826). Teorie iuris politiae představuje mezistupeň mezi předchozími snahami o podání systematického přehledu správních předpisů a následujícími výklady o uspořádání a fungování právního státu. Dnes činí obtíže pro pochopení této teorie již to, že jejím jazykem byla převážně latina. Navíc se znalci této teorie často vyznačovali pro nás již př́liš komplikovaným stylem. Tak např́íklad Gerstaecker je považován za obzvláště temného autora. Přitom se vlastně jenom snažil vysvětlit, co vlastně objevil Immanuel Kant, když v přirozeném právu našel principy odvoditelné z rozumu, a zamýšlel se nad tím, jak může být uskutečňováno zákonodárství. Zdá se však, že přirozenoprávní argumentace tohoto druhu zastiňovala

6 HENDRYCH, D. a kol. Správní právo: obecná část. Praha: C. H. Beck, 2016, s. 15-16. 
to, že se stát měl prostřednictvím právních předpisů a administrativních opatření postarat o blaho občanů, a to i těch, kteří o to ani mnoho nestáli. Vedle teorie iuris politiae je potřebné se zmínit i o povaze politického práva. Montesquieu, o němž se někdy ř́ká, že byl posledním myslitelem, který uvažoval o formách státu a vládnutí smrtelně vážně, používá pojem le droit politique, aby zdůraznil, že v politickém kontextu nejde ani tolik o zájem prosazovaný úřady, ale o celkové vztahy mezi vládnoucími a ovládanými. Rousseau používal výraz bonne politie, když měl na mysli civilizované uspořádání vztahů mezi vládnoucími a ovládanými.

Tím se však dostáváme ještě hlouběji do historie. Již na samotném počátku 18. století nás Nicolas de La Mare ve svém díle Traité de la police upozorňuje, že francouzským slovem police označujeme velice různorodé formy vládnutí, a svůj výklad odvíjí od Platóna a Aristotela. V latině se tehdy ještě hojně používalo slovo politia, šlo ovšem o pozdně latinský termín z období, kdy již na Západě upadla mezi vzdělanci znalost řečtiny. S přihlédnutím k řecké tradici tak termín policie, označující nyní většinou jen represivní složku státu (i když pomáhá a chrání), byl synonymem pro veřejnou správu. Označovalo se tak umění vládnout společnosti a vytvářet pravidla zabezpečující pořádek a blahobyt. Blíže k právnickému pojetí se zároveň uplatnil význam optimálního stavu, řádu či uspořádání pro ty, kteří tvoří obec, pospolitost či stát. Ze starší české literatury lze připomenout knihu Politia historica, kterou vydal v roce 1584 Daniel Adam z Veleslavína. Hlavní titul díla, které je adaptací německého Regentenbuchu právníka a humanisty Georga Lauterbecka, vychází z toho, že předloha je svým autorem označena jako Buch der historischen Polizey. I zde jde o reminiscenci na Aristotela, který smíšenou formu považoval za dobrou formu vlády a nazýval ji politeiá. Kniha se obrací na vládce, výraz regent překládá Veleslavín do češtiny slovem správce. Na řadě míst najdeme úvahy o vázanosti správce dobrým právem a zajisté musí i současníka potěšit úvaha o tom, že není radno právo měnit, pokud obci neškodí. V žádném prŕípadě si správce nesmí nové právo vymýšlet pro vlastní užitek.

Historické ohlédnutí můžeme ukončit na počátku 15. století, kdy bylo ještě před rozšíŕením knihtisku sepsáno dílo Livre du corps de policie, jehož opisy vzbudily ve své době značnou pozornost a které je i v současnosti čteno díky kritickým edicím. Text je dílem všestranně vzdělané Kristiny Pisánské, která vedle beletrie napsala i několik děl naučných a poučných a neváhala se vyjadřovat o politice, vojenství a právu. Její politická vize vychází z metafory poslušnosti částí těla vůči hlavě. Humanistická orientace se projevuje v představě, že v politickém těle musí existovat vyvážená, nikoli vynucená rovnováha, přičemž důraz je kladen na koordinaci činnosti různých orgánů. Hlava politického celku má nejenom přirozenou autoritu, ale i odpovědnost. Vládce je tak považován především za služebníka celku. Studium prací z pozdního středověku a raného novověku vedlo řadu autorů k úvahám o pozvolné proměně středověkého konstitucionalismu do klasické podoby, soustředěné na klíčové otázky dělby moci a občanské svobody.

Jev, který jsme již dříve nazvali normativní dualitou, v níž je diskreční pravomoc komplementárně posuzována z hlediska ústavního i správního práva, však zůstává za tímto vývojem skryt. Recentní učebnice správního práva upozorňují zpravidla na to, že právní vývoj ve sféře veřejné správy se v mnoha evropských zemích nutně opožd'oval 
tam, kde se správní právo nevyvíjelo rovněž jako právo soudcovské, ale jen jako právo policejních opatření, často nejen nepopulárních, ale i nesmyslných. ${ }^{7} \mathrm{~V}$ komparativistické literatuře tento vývoj pregnantně už před více než stoletím uchopil F. J. Goodnow. Ztotožnil se s názorem, že správní právo se vyvíjelo jako právo povinností, zatímco ústavní právo jako právo práv. ${ }^{8}$

Na sklonku osvícenské doby se v mnoha zemích setkáváme s úvahami o tom, že to, co ve správním právu obsaženo je, tam být nemá, zatímco mnoho podstatného tam nalézt nelze. Něco $z$ toho je spojeno s představami politika a literáta jménem Henry Saint John, o němž se psalo, že míchal hanebné orgie s nejvyššími státnickými povinnostmi, a který v roce 1712 získal titul vikomt Bolingbroke. Protože platí, že ne každý může být prorokem ve vlastní zemi, ovlivnil Bolingbroke zejména republikánské myšlení a s oblibou ho četli Adams, Jefferson i Madison. Dodnes jsou připomínána jeho tři vyjádření: - ústavou jsou zákony, instituce a zvyky tvořící konsensus o tom, jak chce být společnost spravována;

- vládou je to, co činí úředníci, jimž je svěřena správa věcí veřejných;

- dobrá vláda (a správa) je v souladu s ústavou.

Odtud je jen krůček k okřídlenému Painovu vyjádření o tom, že ústava předchází vládu, protože vláda je ústavním výtvorem. Zbývá dodat, že je-li tomu tak, netřeba se práva bát, protože se nepotřebujeme osvobodit od práva, ale stáváme se svobodnými díky právu. Co však zbývá, nerespektují-li lidé vládu, která byla zvolena, a zároveň ospravedlňují porušování povinností?

V duchu uvažování nastíněného v 18 . století platí, že podaří-li se udržet dobrou vládu, tedy vládnutí na ústavním základě, neměly by vzniknout větší problémy s veřejnou správou. Vývoj veřejného práva probíhal však přinejmenším od poslední třetiny 19. století v západních společnostech velmi rychle a nedá se říci, že by se správní právo schovalo do zákrytu práva ústavního. Veřejná správa se diferencovala a její odpovědnostní vztahy k ústavním orgánům se komplikovaly. Vlády začaly čelit protichůdným tlakům v souvislostech regulačních výzev spojených s urbanizací, industrializací a mondializací trhů. Zároveň se v tomto období projevily znaky toho, že oddělení regulační moci od demokratické a ústavní legitimity se stává jedním z identifikačních atributů správy věcí veřejných. ${ }^{9}$ Veřejná správa se judicializovala a pro mnohé administrativisty se pojem právní stát zúžil na „stát se správními soudci“. Právníci se více než právu začali věnovat realitě právní ochrany. $\mathrm{V}$ tomto ovzduší se zrodilo institucionální pojetí práva, které se stalo výzvou pro liberální konstitucionalismus. ${ }^{10}$

Institucionalismus má řadu různých variant, ale společné je pojetí práva jako institucionální skutečnosti. Bez pochopení této skutečnosti zůstane právní znalost fragmentární, protože existuje tolik právních řádů, kolik je institucí. Proto institucionalisté

\footnotetext{
7 Tamtéž, s. 10 .

8 GOODNOW, F. J. Comparative Administrative Law. New York: Burt Franklin, 1903, reprinted 1970, s. 8.

9 LINDSETH, P. L. Between the 'Real' and the 'Right': Explorations along the Institutional-Constitutional Frontier. In: ADAMS, M. - MEUWESE, A. - BALLIN, E. H. (eds.). Constitutionalism and the Rule of Law. Cambridge: Cambridge University Press, 2017, s. 85-86.

${ }^{10}$ LUTHER, J. Realism and Idealism in the Italian Constitutional Culture. In: ADAMS, M. - MEUWESE, A. - BALLIN, E. H. (eds.). Constitutionalism and the Rule of Law. Cambridge: Cambridge University Press, 2017, s. 333-334.
} 
zdůrazňují, že ústavní právo není vyčerpáno normami, které upravují vztahy uvnitř státu a vztahy státu a jednotlivců, zrovna tak jako právo upravující správní vztahy zároveň fixuje strukturu a funkci veřejné správy. Konstitucionalistická konstrukce opírající se o představu demokracie a umírněného vládnutí je konfrontována s institucionální skutečností veřejné správy. I když se správní předpisy rychle mění, institucionální struktury veřejné správy mají velkou setrvačnost a jsou relativně trvalé. ${ }^{11}$

Michel Foucault ve filozofické reflexi institucionální skutečnosti spatřoval proměnu moci, která dala vzniknout sadě specifických nástrojů vládnutí a umožnila i vznik sady specifických vědomostí. Stát možná je, říká Foucault, pouze složenou realitou a mytizovanou abstrakcí. Důležitá pro naši modernost, to znamená pro naši současnost, není etatizace, ale to, co lze nazvat governmentalizaci státu. ${ }^{12}$ Foucaultův koncept nalezl značný ohlas i ve správní vědě, která $\mathrm{v}$ druhé polovině 20 . století musela vstřebat důsledky poznání, že veřejná správa může mít toliko omezenou racionalitu při řešení společenských problémů. Tím byly odmítnuty pokusy kř́sit státní paternalismus a konzervativní governmentalismus jako konstrukci, podle níž má vláda vůdčí aktivní roli ve společnosti a projevuje tendenci v průběhu času expandovat. Domyšlení toho, jak omezená racionalita při správě věcí veřejných funguje, totiž ukazovalo, že se každá vláda v průběhu času opotřebovává, což je jistě vítané pro účely minimalizace státu, ale nepř́ijemné potud, že není zřejmé, kdo a co může vládu nahradit.

Přejmenovat gouvernance na gouvernementalité se může jevit jako hra se slovy. Ve správní vědě je však důležité odlišit ovládání od zvládání. A důležité je to i z hlediska jurisprudence, zejména uvažujeme-li o použitelnosti různých nástrojů, které jsou v právním řádu obsaženy.

\section{KONSTITUCIONALIZACE SPRÁVNÍHO PRÁVA}

Právní obory se obvykle rozlišují podle pramenů a předmětu regulace, při rozlišení veřejnoprávních a soukromoprávních oborů je významná i charakteristická metoda regulace. Pokud jde o prameny, ústavní právo se ve svých různých podobách opírá nejen o psanou ústavu, ale i o některé mezinárodní smlouvy, významná soudní rozhodnutí a v neposlední řadě o ústavní zásady a zvyklosti. Chápeme-li správní právo jako konstitucionalizované odvětví, znamená to, že část ústavních předpisů, ale i principů se stává rovněž prameny správního práva. Pokud jde o obsah, lze se dobře opřít o Kyselovo zjištění, že ústavní právo vytvárí rámec, v němž se odehrávají politické procesy (politics), a to mezi vesměs jím regulovanými aktéry různého typu (polity), a k otázkám, jež považuje za př́ipustné (policy), přičemž jako každé jiné právo je i to ústavní výsledkem politiky. ${ }^{13}$ Správní právo můžeme na obdobné úrovni obecnosti ob-

11 GINSBURG, T. Written constitutions and the administrative state: on the constitutional character of administrative law. In: ROSE-ACKERMAN, S. - LINDSETH, P. L. (eds.). Comparative Administrative Law. Cheltenham: Edward Elgar, 2010, s. 121-122.

12 FOUCAUlT, M. Security, Territory, Population. New York: Palgrave MacMillan, 2009, s. 108-109.

13 KYSELA, J. Poznámky ke stavu oboru ústavního práva a státovědy. Časopis pro právní vědu a praxi. 2017 , roč. 25 , č. 3 , s. 377 . 
sahově ztotožnit s tím, čemu se dříve říkalo politia a co dnes chápeme jako souhrn úkolů a jim odpovídajících prostředků veřejné politiky.

Konstitucionalizace se týká různých oborů práva, a to nejenom veřejnoprávních. Ústavně konformní interpretace norem může do jisté míry řešit problémy plynoucí z fragmentarizace právní úpravy, záleží ovšem na tom, kdo, co a jak vykládá. Téměř vždy je zdůrazňováno, že konstitucionalismus reflektuje historické zkušenosti s těmi, kteří podléhají svodům libovůle a zneužití práva. V návaznosti na to měla být konstitucionalizace ku prospěchu slabším a v rozumné míře omezit diskreci ve vertikálních právních vztazích, či autonomii vůle ve vztazích horizontálních. Poměrně dlouho se takto realizoval ideál omezené vlády. V současnosti však pozorujeme, že konstitucionalizace přesahuje politické hranice a chce napomáhat tomu, aby lépe fungovala i správa jako taková.

K dokreslení těchto úvah lze využít dva př́ípady z naší právní praxe. Na prvém z nich lze vhodně ukázat, že konstitucionalizace se může týkat jakéhokoli právního sporu, není tedy nutně provázána s veřejným právem. Konstitucionalizace míř́ za hranice organické i lidskoprávní části ústavního práva a v jednotlivých právních oborech, které ovlivňuje, rozšiřuje argumentárium tak, že přenáší váhu mezi pravidly a principy, podle nichž má být sporná otázka rozhodnuta. V případu společnosti DEMVED, a. s., Ústavní soud indikoval interpretaci práva, která se dostala do extrémního rozporu s principy spravedlnosti. ${ }^{14} \mathrm{~V}$ rozhodování obecných soudů bylo pominuto v konkrétním ekonomicko-právním vztahu jeho těžiště tak, aby byl nalezen nejen optimální užitek pro smluvní strany, ale aby bylo dosaženo spravedlivého stavu. Do hry tak vstoupil pojem dobré mravy, který nelze vykládat pouze jako soubor mravních pravidel užívaných jako korektiv či doplňující obsahový faktor výkonu subjektivních práv a povinností, ale jako př́kaz soudci rozhodovat v souladu s ekvitou. Konstitucionalizace se proto úzce dotýká právních situací, v nichž se balancuje na hranici využití a zneužití práva.

Skutkově nešlo o složitou věc. V roce 2006 byla uzavřena smlouva o prodeji bytu. Tuto transakci však prodávající začala zhruba po deseti letech zpochybňovat, vyvolala soudní spor a účelově od smlouvy odstoupila. Soudy zpočátku upřednostnily výklad, který nezakládá neplatnost právního jednání, před výkladem, který neplatnost právního jednání zakládá, je-li obojí výklad možný. Navíc jednání prodávající hodnotily jako nemravné. Jiný názor měl dovolací soud, který v podstatě argumentoval tak, že prodávající - byt' poněkud opožděně - hájí své vlastnické právo. Nejvyšší soud v implicitně řešené právní otázce nemravnosti podané určovací žaloby vytkl, že nebyly dostatečně reflektovány ustálené závěry judikatury dovolacího soudu v otázce, zda lze takovýto aplikační názor vskutku zaujímat právě při podání žaloby, odvíjející se od ústavně garantovaného práva vlastníka. Dodejme, že v našem občanském zákoníku je výslovně uvedeno, že každé ustanovení soukromého práva lze vykládat jenom ve shodě s ústavním pořádkem a že výklad a použití právního předpisu nesmí být v rozporu s dobrými mravy. Zasáhne-li konstitucionalizace otázku mravného či nemravného jednání, znamená to, že dobré mravy, které mají samy povahu základních společenských norem, přestávají fungovat jako autonomní pojem občanského práva.

14 Nález Ústavního soudu ze dne 11. května 2021, sp. zn. IV. ÚS 3542/20. 
Jestliže Nejvyšší soud dovodil, že nižší soudy zasáhly do ústavně zaručeného práva prodávající vlastnit majetek, pak Ústavní soud v roce 2021 uzavřel své posouzení tak, že obecné soudy nevzaly v úvahu všechny podstatné skutečnosti. $\mathrm{V}$ důsledku toho tyto soudy nekvalifikovaly jednání prodávající jako odporující dobrým mravům a svým postupem porušily ústavně zaručené právo kupující na ochranu majetku. Je patrné, že konstitucionalizace v horizontálních vztazích umožňuje zjednodušit argumentaci a nepřihližet k tomu, že určitý obor je přeregulovaný a stanoví pravidla s rozdílným dopadem pro jednotlivé strany. Přitom dovolací soud spíše přitakal přeregulovanosti, zatímco stanovisko soudů rozhodujících na počátku sporu, jakož i verdikt Ústavního soudu, vyšly z poměrně jednoduché myšlenky, že důvěra je pro závazkový vztah základem spravedlnosti. Kdo ohrožuje důvěryhodnost jednání a právní jistotu tím, že zpochybní - fakticky i právně - to, proč došlo $\mathrm{k}$ dohodě, zpravidla nemá mít šanci na úspěch v soudním sporu. Účelem smlouvy totiž nemohlo být to, aby jen jedna strana po určitou dobu používala výhodu, kterou transakcí získala. Jinými slovy, ústavní přezkum indikoval, že důvěru v to, na čem se strany dohodly, nelze marginalizovat, protože jinak by se soudní ochrana stala neúčinnou.

Bylo by zajisté možné namítnout, že se uvedený př́iklad dotýká soukromého práva a v jeho rámci výlučně horizontálních právních vztahů a že není zajímavý z hlediska našeho tématu. Není však možné přehlédnout, že důvěryhodnost jednání je v mnoha ohledech klíčovým momentem i pro správní právo, jak se pokusí ukázat druhý př́íklad ze soudní praxe. $V$ tomto prípadě šlo primárně o to, $\mathrm{k}$ čemu se zavázala škola, která přijala žáka ke studiu, konkrétně pak o povinnost školy učit prezenční formou poté, co byl školský zákon v roce 2020 doplněn o pravidla týkající se omezení osobní přítomnosti studentů ve školách z důvodu krizového či mimořádného opatření nebo karantény.

Správnímu soudu připadla žaloba proti Gymnáziu Na Zatlance směřující k tomu, aby soud přikázal obnovit prezenční výuku. Městský soud žalobě vyhověl..$^{15} \mathrm{O}$ tři dny později přiznal Nejvyšší správní soud kasační stížnosti gymnázia odkladný účinek. ${ }^{16}$ Za necelých pět měsíců pak Nejvy̌šsi správní soud rozsudek Městského soudu v Praze zrušil. ${ }^{17}$

Městský soud uznal, že student realizuje své právo na vzdělání a zároveň povinnost chodit do školy tím, že byl přijat na školu do denního studia, což je nutno chápat jako vzdělávání založené na osobní př́tomnosti ve škole. Školy jsou povinny řádně vzdělávat žáky a zároveň mají právo na to, aby do této jejich činnosti stát nezasahoval omezeními či zákazy. To vedlo soud k přezkoumání krizového opatření jako konkrétního zmocnění umožňujícího aktivovat distanční výuku. Předpokladem pro vydání krizového opatření je existence nouzového stavu, který je upraven ústavním předpisem. Městský soud tedy provedl ústavní analýzu nouzového stavu. Shledal, že dotčené krizové opatření povstalo z protiústavně vyhlášeného nouzového stavu. Šlo - jak soudce expresivně vyjádřil o plod otráveného stromu. Pokud bychom se omezili na správní právo, nemohli bychom dospět k závěru, že škola způsobila distanční výukou nezákonný zásah do práv studentů,

\footnotetext{
15 Rozsudek Městského soudu v Praze ze dne 23. února 2021, č. j. 17 A 126/2020-84.

16 Usnesení Nejvyššího správního soudu ze dne 26. února 2021, č. j. 6 As 73/2021-20.

17 Rozsudek Nejvyššího správního soudu ze dne 20. července 2021, č. j. 6 As 73/2021-67.
} 
protože škola byla podle principu legality povinna realizovat krizové opatření. Zjištění protiústavnosti vyhlášení nouzového stavu se tak stalo alfou a omegou celého rozsudku.

Nejvyšši správní soud se ve svém procedurálním usnesení o odkladném účinku pochopitelně nezabýval ústavní analýzou nouzového stavu. Ústavněprávní úvahy však zmíněné usnesení nepostrádá. Rozhodnutí vycházelo z toho, že dotčeným zájmem na straně žalobce je zejména realizace jeho práva na vzdělání v kontextu dlouhodobého omezení prezenční výuky. Nejvyšší správní soud přitom zohlednil zřejmou závažnost pandemické situace a vzal v úvahu, že nižší soud neposkytl žádnou lhůtu k přijetí nezbytných opatření, která by mohla účinně snížit riziko šíření původce nemoci covid-19 při prezenční výuce a následně v rodinách studentů $i$ zaměstnanců. Pro účely prozatímního rozhodnutí Nejvyšší správní soud dospěl k závěru, že zájem na ochraně veřejného zdraví v projednávané věci bezprostředně převažuje nad právem žalobce. V poměrně obsáhle odůvodněném usnesení byly použity principy předběžné opatrnosti a proporcionality. Nař́dit obnovení stavu před pandemií má pochopitelně smysl tehdy, jestliže to je bezpečně uskutečnitelné. $O$ realističnosti tohoto př́kazu byly však zásadní pochybnosti. Při soudním řízení muselo být zřejmé, že obnovením kontaktní výuky v této škole by se $\mathrm{v}$ dané epidemiologické situaci ocitla $\mathrm{v}$ př́mém ohrožení zdraví skupina lidí v počtu dvou až tří tisíc osob, přičemž některé z těchto osob by mohly být i ohroženy na životě, což odpovídá zákonitostem komunitního šíření a průběhu nemoci. Judikatura Nejvy̌ššího správního soudu přitom zastává názor, že v př́ípadech, kdy je kasačním stěžovatelem veřejnoprávní orgán, lze přiznat odkladný účinek pouze výjimečně. Odložení účinků rozhodnutí městského soudu bylo podmíněno ochranou dủležitého veřejného zájmu, jehož ohrožení v konkrétním př́padě představovalo právě onu nepoměrně větší újmu, než která přiznáním odkladného účinku vznikne jiným osobám.

Je patrné, že i v pouhém procesním rozhodnutí, které může být pochopeno jen jako věc soudní rutiny, se mohou projevit prvky ingerence ústavního práva. Nejvyšší správní soud považoval bezodkladné rozhodnutí o odkladném účinku za nutné k nastolení jistoty ohledně možných dopadů na větší sociální skupinu s ohledem na bezpečí života a zdraví a zároveň konstatoval, že studentovi nebylo odepřeno právo na vzdělání jako takové a $\mathrm{v}$ úplnosti.

V rozhodnutí, kterým Nejvyšší správní soud posléze rozsudek Městského soudu zrušil, se konstitucionalizace již neprojevuje v rovině lidskoprávní, ale jen organickou argumentací. Zásadní je odpověd' na repliku ke kasační stížnosti, z níž se podává, že účelem žaloby nebylo zakázat vládě vydávat opatření en bloc, ale obnovit na konkrétní škole prezenční výuku protizákonně a možná i protiústavně pozastavenou. Městský soud se to také tímto způsobem snažil řešit, přehlédl však, že vztah žáka a školy nemá vyhraněně vertikální povahu, a neodhadl, kam se posouvá rozhodovací praxe Nejvyššího správního soudu. Podle následné judikatury přerušení prezenční výuky není dáno rozhodnutím či jiným aktem školy, ale plyne již př́mo z krizového opatření vlády. Vztah školy a žáka měl horizontální povahu a vyhovět jednomu žáku by znamenalo ohrozit velkou skupinu lidí. Konstitucionalizační účinek by se ve prospěch strany, která jednala důvěryhodně - podobně jako ve výše uvedeném soukromoprávním případě - projevil jen při př́padném porušení práva na účinnou soudní ochranu. Rozsudek Městského soudu musel být zrušen, nebot' nebyly v dané věci splněny podmínky řízení, na nichž 
je založeno naše správní soudnictví. Nejvyšší správní soud to v závěru odůvodnění kasačního verdiktu vyjádřil spíše konstitucionalistickou nežli administrativistickou rétorikou: ,,Soudy si nemohou své kompetence libovolně rozšiřovat s tím, že to bude v zájmu nějakého vyššiho dobra. Expanzivní výklad soudnich pravomocí by neprispěl k ochrané zákonnosti a hodnot právního státu, ale naopak $k$ erozi těchto hodnot a k právní anarchii. "18

Dodejme ještě, že zjišstování protiústavnosti vyhlášení nouzového stavu, o něž se opíral prvoinstanční rozsudek, když krizové opatření považoval za plod otráveného stromu, tak pozbylo v kontextu celého př́ípadu smysl. Nadto Ústavní soud dovodil, že vyhlášení nouzového stavu vládou primárně představuje akt aplikace ústavního práva, který má normativní důsledky, nebot' aktivizuje hypotézy norem obsažených v některých zákonech. Jde o mimořádný, specifický ústavní akt vydaný za situace, kdy existuje nebezpečí, které ve značném rozsahu ohrožuje životy a zdraví. Ani Ústavní soud nemá stanovenu pravomoc takové rozhodnutí vlády přezkoumávat. ${ }^{19}$

V tomto př́íspěvku není prostor pro obsáhlou analýzu judikatury týkající se mimořádných opatření, i když jde z hlediska vztahu ústavního a správního práva o velmi zajímavou materii. Všimněme si v této souvislosti již jen komplikovanosti ústavně konformní interpretace jedné kompetenční normy, která se opět týká provozu škol. Z judikatury potvrzené $\mathrm{v}$ prvních měsících po vypuknutí epidemie $\mathrm{v}$ roce 2020 vyplývalo, že i v době, kdy není vyhlášen nouzový stav, ustanovení § 69 odst. 1 písm. b) zákona o ochraně veřejného zdraví výslovně Ministerstvu zdravotnictví svěřuje pravomoc rozhodnout o uzavření škol nebo omezení jejich provozu. Ustanovení § 80 odst. 1 písm. g) zákona o ochraně veřejného zdraví bylo vykládáno tak, že Ministerstvo zdravotnictví má v př́ípadě epidemie pravomoc uzavř́í školy na území celé České republiky. Žádný právní předpis přitom nestanovil, že by tato pravomoc byla Ministerstvu zdravotnictví odňata $\mathrm{v}$ př́ípadě vyhlášení nouzového stavu. ${ }^{20}$

Tato poměrně jasná a $\mathrm{z}$ textace zákona zřejmá interpretace byla po zkušenostech $v$ průběhu pandemie pozměněna judikatorním odklonem. Bylo naznáno, že $\S 69$ odst. 1 písm. b) zákona o ochraně veřejného zdraví je ze své povahy určen spíše $\mathrm{k}$ časově a místně omezeným protiepidemickým opatřením, která jsou podmíněna konkrétním podezřením na výskyt nákazy u konkrétního okruhu osob. Nejde a nemůže jít o plošný nástroj podobný tomu, jaký má po dobu nouzového stavu $\mathrm{k}$ dispozici vláda. ${ }^{21}$ Krizová opatření v nouzovém stavu se tak zhruba po roce pandemie v mysli některých správních soudců stala jediným nástrojem prevence nákazy. Jen tak mělo být možné vykonávat veřejnou správu, aby ústavně zaručené právo na ochranu zdraví neztratilo v reálných životních podmínkách smysl a aby byl naplněn účel ústavní kautely, podle níž svoboda pohybu, jestliže je to nevyhnutelné pro ochranu zdraví, může být omezena zákonem a práva na vzdělání se lze domáhat pouze $\mathrm{v}$ mezích prováděcích zákonů.

Je známo, že interpretace zákonů ne vždy vede k právní jistotě. Lze samozřejmě namítnout, že ve zvláštní situaci, za jakou je pandemie obvykle považována, může být in-

\footnotetext{
18 Tamtéž, bod 16.

19 Usnesení Ústavního soudu ze dne 16. března 2021, sp. zn. Pl. ÚS 12/21, bod 17.

20 Rozsudek Městského soudu v Praze ze dne 7. května 2020, č. j. 10 A 35/2020-261, bod 53

21 Rozsudek Nejvyššího správního soudu ze dne 2. června 2021, č. j. 10 Ao 2/2021, bod 54.
} 
terpretace správních zákonů poněkud zvláštní. Tomu by odpovídala okř́́dlená klasifikace správního práva na řádné a mimořádné. Je ovšem velice zvláštní, nedokáže-li soudce dva nebo tři měsíce dopředu odhadnout, jak kontraproduktivní výklad zákona zastává. Tak v již zmiňovaném zrušeném rozsudku z konce února 2021 čteme: , Bylo možné také zaznamenat, že postup vlády při vyhlášeni , nového 'nouzového stavu je ospravedlňován povinností státu chránit životy a zdraví občanů. Takový prístup vychází z nepodložené premisy, že nouzový stav je jedinou alternativou k ochraně životů a zdravi při probihající pandemii. To není vi̊bec jednoznačné (stěži lze tvrdit, že bez vyhlášení nouzového stavu by nebylo možno chránit životy a zdraví), ostatně na jaře loňského roku byly ke zvládáni pandemie - na rozdíl od současného stavu - hojně využivány jiné nástroje, a to mimořádná opatřeni ministerstva zdravotnictvi podle zákona o ochraně veřejného zdravi [...]. "22 Za dva měsíce byla verze o kompetenčních alternativách zpochybněna: „Ustanoveni § 69 odst. 1 písm. b) zákona o ochraně veřejného zdravi umožňuje zásah do rady ústavně zaručených základnich práv (svobody pohybu a shromažd'ování, práva na ochranu zdravi či práva na vzdělání) a jako takové musi být vykládáno restriktivné, tedy tak, že umožn̆uje zakázat nebo omezit styk jen těch skupin fyzických osob, u nichž existuje konkrétní podežrení z nákazy či vyšši riziko, že by mohly být nakaženy [...]. "23 Za další měsíc se již naplno dozvídáme, že Nejvyšší správní soud jednoznačně odmítá to, aby mohla být vydávána plošná opatření podle $\S 69$ odst. 1 písm. b) zákona o ochraně veřejného zdraví z preventivních důvodů. ${ }^{24} \mathrm{O}$ necelé dva týdny později je tato myšlenka rozvinuta takto: ,, Ministerstvo ve skutečnosti použivá § 69 odst. 1 písm. b) takovým způsobem, [...] jako by mezi jeho pravomoci při epidemii patřilo obecně a bez dalšich podminek omezit svobodu pohybu všem obyvatelům země, zakázat veškerá predstavení, zavřit všechny školy a všechny restaurace apod. Podobné úvahy však nejen že jsou obtižně přijatelné z ústavněprávního hlediska ([...] k podobně razantním zásahuim je určen nouzový stav), ale ani nemaji žádný podklad ve znění zákona. [...] Soud shrnuje, že § 69 odst. 1 písm. b) zákona o ochraně veřejného zdraví je ze své povahy určen spiše k časově a mistně omezeným protiepidemickým opatřením, která jsou podminěna konkrétním podezřením na výskyt nákazy u konkrétního okruhu osob. Nejde a nemůže jít o plošný nástroj podobný tomu, jaký má po dobu nouzového stavu k dispozici vláda [...], " a nelze jej použít k plošnému uzavření či omezení provozu všech škol. ${ }^{25}$

Podle administrativistické konstrukce potvrzené ustálenou soudní praxí je míra volnosti uvážení správního orgánu limitována zákazem libovůle, přičemž rozhodnutí podléhá přezkumu soudu pouze $\mathrm{v}$ tom směru, zda nevybočilo z mezí a hledisek stanovených zákonem, zda je v souladu s pravidly logického usuzování a zda premisy takového úsudku byly zjištěny řádným procesním postupem. Jsou-li tyto předpoklady splněny, není soud oprávněn z týchž skutečností dovozovat jiné nebo přímo opačné závěry, pokud by správní orgán neučinil zjevnou chybu v hodnocení faktů. Diskreční omyl tohoto typu může implikovat chybu, která je extrémní a zjevná zároveň a soud ji může dete-

22 Rozsudek Městského soudu v Praze ze dne 23. února 2021, č. j. 17 A 126/2020-84, bod 44.

23 Rozsudek Nejvyššího správního soudu ze dne 22. dubna 2021, č. j. 6 Ao 11/2021-48, bod 75 .

24 Rozsudek Nejvyššího správního soudu ze dne 21. května 2021. č. j. 6 Ao 22/2021-44, bod 45.

25 Rozsudek Nejvyššího správního soudu ze dne 2. června 2021, č. j. 10 Ao 2/2021-107, body 51 a 54 . 
kovat jen letmým dotykem v jednom či dvou odstavcích odůvodnění rozsudku. Může však také jít o chybu, která je velmi závažná, ale projeví se až po důkladném zjištování skutečností v rámci soudního řízení. Například pro judikaturu Evropského soudního dvora je př́značné, že argumentárium je velice rozsáhlé, zabere několik desítek stran textu odůvodnění a substituuje správní opatření. ${ }^{26}$

Pro soudy je samozřejmě snazší hledat právní vady, např́íklad konstatovat absenci zmocnění vydat správní akt. Správněprávní odůvodnění reinterpretace kompetenční normy musí být $\mathrm{v}$ zájmu právní jistoty bezpodmínečně striktní. S přechodem do sféry ústavního práva se nabízí možnost nahradit přesnost omezeností. Proto jsme se setkali s tvrzením, že ustanovení § 69 odst. 1 písm. b) zákona o ochraně veřejného zdraví musí být vykládáno restriktivně. Zužující výklad omezuje veřejnou správu, může být odůvodněn konstitucionalisticky, ne však governmentalisticky. Právo může veřejnou správu ovládnout, ne však zvládnout pandemii. Pro někoho je přednější svoboda pohybu, pro dalšího právo na vzdělání a pro jiného právo na ochranu zdraví. Restriktivní výklad kompetenční normy nic neřeší, není-li jasné, k jakému řešení konfliktu práv směřuje. Administrativisté proto připomínají, že stejně tak jako o konstitucionalizaci správního práva je třeba uvažovat i o jeho dekonstitucionalizaci. ${ }^{27}$

Debata o paralelních vlivech, které působí na to, zda bude konstitucionalizační vliv na správní právo sílit nebo slábnout, se $\mathrm{v}$ současnosti vede zejména $\mathrm{v}$ rámci komparativních studií. ${ }^{28} \mathrm{Na}$ tomto místě se již jen pokusíme stručně shrnout, jaké teoretické př́stupy jsou stále živé, i když byly nastíněny $\mathrm{v}$ minulých dobách, kdy veřejná správa i společnost vypadaly jinak než dnes.

Se vznikem ideje ústavního státu se vyloučení veřejné správy z dosahu ústavy stalo téměř nemyslitelným. Umírněné př́ístupy představitelů pozitivní jurisprudence se shodovaly na komplementárním pojetí, které Jiř́ Pražák vyjádřil takto: ,,Nelze vytknouti přesných hranic mezi právem ústavním a správním, nebot’ se navzájem doplňuji. "29 Variantu tohoto pojetí zastávali i někteří stoupenci normativních škol. Připomeňme dílo, které bylo zpř́stupněno i v českém překladu a jehož autorem je Adolf Merkl. Veřejná správa byla představována jako $v$ podstatě zcela pravidelná činnost a správní právo jako součást stupňovitě uspořádaného právního řádu, a to jako souhrn norem př́kazních. Právní stát se vyznačoval ,náležitě upraveným správním právem “ určujícím obsah veškerých správních jednání. ${ }^{30}$ Merkl se v této souvislosti dovolával autority Otty Mayera, který však měl o veřejné správě realistické mínění a nepatřil $\mathrm{k}$ učencům, kteří by se snažili klást zásadní důraz na normativní vyjádření podstaty exekutivy a administrati-

26 CRAIG, P. Law, Fact and Discretion in the UK, EU and the USA. In: La chaire Mutations de l'Action Publique et du Droit Public, Sciences Po [online]. 2007, s. 10-11 [cit. 2021-05-18]. Dostupné na: https:// www.sciencespo.fr/chaire-madp/sites/sciencespo.fr.chaire-madp/files/paul_craig.pdf.

27 WOLLENSCHLÄGER, F. Constitutionalisation and deconstitutionalisation of administrative law in view of Europeanisation and emancipation. Review of European Administrative Law. 2017, roč. X, č. 1, s. 7-79.

28 HEUSCHLING, L. The complex relationship between administrative and constitutional law: a comparative and historical analysis. In: VON BOGDANDY, A. - HUBER, P. M. - CASSESE, S. (eds.). The Max Planck Handbooks in European Public Law. Vol. 1, The Administrative State. Oxford: Oxford University Press, 2017, s. 49-56.

29 PRAŽÁK, J. Rakouské právo ústavní. Část první. Praha: Národní knihtiskárna a nakladatelstvo, 1895, S. 15.

30 MERKL, A. Obecné právo správní. Díl první. Praha - Brno: Orbis, 1934, s. 79. 
vy a zdůrazňovali hierarchickou stavbu právního řádu s ústavním právem na vrcholu pyramidy. Pro Mayera bylo stěžejní fungování veřejné správy, čili obligátní a běžná činnost, která jen v ideálním př́padě mohla být vykonávána důsledně legalistickým a nestranným způsobem. Mayer jako znalec droit administratif nejednou připomínal, že z francouzského hlediska je přirozené, že se mění ústavní právo, zatímco správní právo přetrvává. Tuto myšlenku včlenil i do předmluvy k třetímu vydání své učebnice německého správního práva v reakci na ústavní změny spojené s politickým vývojem těsně po první světové válce. Mayerova maxima o stálosti správního práva byla většinou chápána jako výzva k udržení stability v předtuše toho, co nazýváme přeregulovaností veřejné správy. Pro úplnost dodejme, že podobně již dříve uvažoval ve Francii Théophile Ducrocq. Pro francouzské právní myšlení to ovšem byla také trochu zvláštnost, protože od doby kodifikace občanského práva se atribut stálosti obvykle přičítal soukromému právu oproti veškerému právu veřejnému.

Ve druhé polovině 20. století se setkáváme s řadou koncepcí reflektujících to, že vztah ústavního a správního práva je v interpretační i aplikační rovině spíše napjatý než konsolidovaný. Na konci padesátých let vystoupil Fritz Werner s apodiktickým pojetím správního práva jako konkretizace ústavních norem. S tím se později ztotožnili i představitelé Neue Verwaltungsrechtswissenschaft, kteří často kritizovali nedostatek ohledu na ústavní principy a pravidla ve veřejné správě. Ústavní purismus ovšem přispíval i k výlučnému zaměření pozornosti na právní akty. Pokud tyto akty prošly kontrolními testy, bylo téměř jedno, co správci věcí veřejných udělali, proč tak činili a zda se jejich kroky ukázaly jako rozumné. S ohledem na postupující evropeizaci správního práva, která byla vnímána jako marginalizace a neutralizace ústavy, se později na tomto základě rozvinula diskuse, zda správní právo přes všechno úsilí nakonec přece jenom nepodléhá dekonstitucionalizaci.

V anglické právní vědě se v témže období většina znalců přikláněla ke komplementárnímu pojetí vztahu ústavního a správního práva. Nelze ovšem říci, že by zcela odezněla příznačná Diceyho nechut' ke správnímu právu kontinentálního střihu. Nahlížení na veřejnou správu prizmatem základních práv, kterému se v posledním období přiblížila většina zemí, v nichž se uplatňuje common law, nebrání čas od času radikálnímu popření smyslu správního práva. Dokladem toho je silně historizující kniha amerického konstitucionalisty Philipa Hamburgera o extralegální povaze exekutivy a administrati$\mathrm{vy}^{31}$

Ani pro současnou francouzskou jurisprudenci není nezajímavá někdejší kontroverze Charlese Eisenmanna dovozujícího, že ústava neříká nic o základech správního práva, a Georgese Vedela, který ústavní základy správního práva nacházel především v judikatuře. ${ }^{32}$ Ostatně nedávno ve své důkladné práci Antoine Faye přesvědčivě hájil myšlenku, že právě droit administratif bylo nejméně do roku 1958 primárním zdrojem

31 HAMBURGER, P. Is Administrative Law Unlawful? Chicago: The University of Chicago Press, 2014, s. 22-24.

32 MAGNON, X. Commentaire sous Les bases constitutionnelles du droit administratif, la controverse G. Vedel/Ch. Eisenmann. In: BENETTI, J. - EGÉA, P. - MAGNON, X. - MASTOR, W. Les grands discours de la culture juridique. 2e éd. Paris: Dalloz, 2017. Online in: Hal: archives-ouveretes.fr [online]. [cit. 2021-05-26]. Dostupné na: https://hal.archives-ouvertes.fr/hal-01725355. 
funkčnosti ústavního práva ve Francii a že tato tradice v judikatuře Státní rady i Ústavní rady stále v mnohém nadále přetrvává. ${ }^{33}$ Podobně jako o konstitucionalizaci správního práva lze tedy za určitých podmínek uvažovat o administrativizaci ústavního práva.

\section{ZÁVĚR}

Ústavní a správní právo jsou obory, které si mohou být blízké i vzdálené. Při řešení veřejnoprávních sporů se často opíráme o argumenty ústavní i správní a pomáháme si interpolací např́íklad tak, že do řady důvodů správních vkládáme ústavní argumenty. Zda tím nalézání práva vylepšíme, anebo zda posouváme právní uvažování k pólu nejistoty, závisí na znalosti rozhraní mezi ústavním a správním právem.

Existuje mnoho faktorů, které vedly ke stavu, v němž se správní regulace v současnosti nachází. Je předimenzovaná, rozporuplná a často i úplně zbytečná. Je třeba přiznat, že na tomto stavu má svůj podíl i konstitucionalistická představa o tom, že správní činnost má být téměř ve všem predestinována vưlí zákonodárce a že delegace normotvorby může představovat pro společnost vážnou hrozbu. Judicializace veřejné správy způsobuje, že soudy mají stále větší podíl i odpovědnost vzhledem $\mathrm{k}$ tomu, jak je formováno právní prostředí a jak má být formalizován výkon veřejné správy. Soužití ústavního a správního práva je za těchto okolností nesnadné a není divu, že v jurisprudenci vyvolává i značně protichůdné reakce.

Pokud lze nalézt pevné shodné body, pak především v tom, že veřejná správa by měla být aktivní v míře přiměřené a že ctností soudnictví by měla být zdrženlivost. Proporcionalita je založena na pochopení toho, že interpolovanou argumentací nelze zvýšit množství primárně získané informace. Jinými slovy, vyvažování je svým způsobem spíše hledání méně špatného než dobrého řešení. Pokud je tedy správní právo v určitém ohledu mlhavé, at' je to již způsobeno jakýmkoli faktorem, budou mlhavé i správní akty. Nelze pritom posílit právní jistotu tím, že se plně spolehneme na právo ústavní. Efekt by byl v lepším případě neutrální, často však by byl spíše opačný. Jestliže je navíc soudce nezdrženlivý, ohrožuje nejenom proporcionalitu, ale i ústavnost, nebot' se snaží řešit to, co je veřejným úkolem legislativy a exekutivy.

prof. JUDr. Richard Pomahač, CSc.

Právnická fakulta Univerzity Karlovy

pomahac@prf.cuni.cz

33 FAYE, A. Les bases administratives du droit constitutionnel: recherche sur la culture administrative du droit constitutionnel. Paris: Fondation Varenne, 2017. 